\title{
PENGARUH STRATEGI PEMBELAJARAN KOOPERATIF THINK PAIR SHARE DAN MINAT BELAJAR TERHADAP HASIL BELAJAR PENDIDIKAN AGAMA ISLAM SISWA SEKOLAH DASAR NEGERI 104192 TANDEM HILIR II DELI SERDANG
}

\author{
Sufairi \\ Guru SDN 104192 Tandem Hilir II Deli Serdang
}

\begin{abstract}
The purpose of this study was to find out: (1) learning outcomes of Islamic Religious students taught with cooperative learning strategies think pair share and expository learning strategies, (2) student learning interest after using the think pair share learning strategy, and (3) the influence of strategy learning and interest in learning about the learning outcomes of Islamic Education. The research was conducted at 104192 Public Elementary School Tandem Hilir II Deli Serdang. This type of research is quasi-experimental. The study population was all class V students spread in 3 classes. The sampling technique used is cluster random sampling. The instruments of data collection are questionnaires and tests. The data analysis technique used is the analysis of two-lane variants on the test $a=$ 0.05. The results showed: (1) the average learning outcomes of Islamic Religious Education students taught with TPS learning strategies $(\bar{X}=$ 29.32) higher than the average learning outcomes of Islamic Religious Education students taught with expository learning strategies $(\bar{X}=27)$ with $\mathrm{F}_{\text {count }}=13.32>\mathrm{F}_{\text {table }}=4.00$, (2) the average learning outcomes of Islamic Education students with high learning interest $(\bar{X}=29.90)$ higher than the learning outcomes of Islamic Education students with low learning interest $(\bar{X}=26.20)$, with $\mathrm{F}_{\text {count }}=10.41>\mathrm{F}_{\text {table }}=4.00$, and (3) there is an interaction between learning strategies and interest in learning with $\mathrm{F}_{\text {count }}=12.51>\mathrm{F}_{\text {table }}=4.00$.
\end{abstract}

Keyword: Cooperative Learning Strategies Think Pair Share, Interest in Learning and Learning Outcomes

\section{PENDAHULUAN}

Pembelajaran Pendidikan Agama Islam pada prinsipnya bertujuan untuk meningkatkan keimanan, pemahaman, dan penghayatan nilai-nilai keagamaan (keislaman), serta pemahamannya. Sehingga kemudian diharapkan dapat menjadi muslim yang beriman dan bertaqwa kepada Allah SWT, serta berakhlaq mulia, dalam arti memiliki kesadaran moral 
yang tinggi dalam kehidupan pribadi dan masyarakat, serta dalam kehidupan berbangsa dan bernegara.

Untuk itu maka diperlukan berbagai upaya dan peran guru dalam mengatasi permasalahan di atas, salah satunya dengan menerapkan strategi pembelajaran yang sesuai dengan keadaan siswanya. Strategi pembelajaran adalah kombinasi yang berurutan dan dirancang agar peserta didik mencapai standar kompetensi. Secara ringkas prinsip pembelajaran saat ini adalah: (1) berpusat pada peserta didik, yaitu bagaimana peserta didik belajar, (2) menggunakan berbagai strategi yang memudahkan peserta didik belajar, (3) proses pembelajaran bersifat kontekstual, (4) interaktif, inspiratif, menyenangkan, memotivasi, menantang dan dalam iklim yang kondusif, (5) menekankan pada kemampuan dan kemauan bertanya dari peserta didik, (6) dilakukan melalui kelompok belajar dan tutor sebaya dan (7) mengalokasikan waktu sesuai dengan kemampuan belajar peserta didik.

Penerapan strategi yang tepat maka materi ajar dalam Pendidikan Agama Islam dapat diserap oleh anak didik dengan sebaik-baiknya. Strategi yang tepat akan menentukan efektifitas dan efisiensi pembelajaran. Sebagai seorang guru pendidik agama Islam maka perlu mengetahui strategi-strategi dalam pembelajaran Pendidikan Agama Islam. Dengan mengetahui strategi-strategi tersebut maka guru diharapkan mampu menyampaikan materi-materi ajaran agama Islam dengan berbagai variasi sehingga tujuan pendidikan agama Islam dapat tercapai dengan lebih mudah.

\section{KAJIAN TEORETSI}

Siregar dan Nara (2011) strategi pembelajaran adalah cara sistematis yang dipilih dan digunakan seorang pembelajaran untuk menyampaikan materi pembelajaran, sehingga memudahkan pembelajaran mencapai tujuan pembelajaran tertentu. Sementara itu strategi pembelajaran menurut Suparman (2012) adalah perpaduan dari (1) urutan kegiatan pembelajaran, (2) cara pengorganisasian materi pengajaran dan siswa, (3) peralatan dan bahan dan (4) waktu yang digunakan dalam proses pembelajaran.

Reigeluth dalam Rusmono (2012) menjelaskan strategi pembelajaran merupakan pedoman umum yang berisi komponenkomponen yang berbeda dari pembelajaran agar mampu mencapai keluaran yang diinginkan secara optimal di bawah kondisi-kondisi yang diciptakan. Melalui penerapan strategi pembelajaran diharapkan hasil 
pembelajarannya dapat berlangsyng secara efektif dan efisien serta memiliki daya tarik tersendiri.

Salah satu jenis di dalam strategi pembelajaran kooperatif adalah think pair share. Srategi pembelajaran kooperatif think pair share dikembangkan oleh Frank Lyman dari Universitas Maryland. Dalam hal ini Arends (2008) menjelaskan bahwa strategi pembelajaran kooperatif think pair share menekankan penggunaan struktur tertentu yang dirancang untuk mempengaruhi pola interaksi peserta didik. Struktur yang dikembangkan dimaksudkan untuk sebagai alternatif untuk struktur kelas yang lebih tradisional seperti resitasi, bahwa tenaga pengajar mengajukan pertanyaan-pertanyaan kepada seluruh kelas dan peserta didik memberikan jawaban setelah mengangkat tangan dan dipanggil namanya.

Pembelajaran kooperatif strategi pembelajaran kooperatif think pair share tetap memperhatikan prinsip-prinsip dasar pembelajaran kooperatif, dalam hal ini Stahl sebagaimana dikutip Solihatin dan Raharjo (2008) yaitu: (1) perumusan tujuan belajar harus jelas, (2) penerimaan yang menyeluruh oleh peserta didik tentang tujuan belajar, (3) ketergantungan yang bersifat positif, (4) interaksi yang bersifat terbuka, (5) tanggung jawab individu, (6) kelompok bersifat heterogen, (7) interaksi sikap dan prilaku sosial yang positif, (8) tindak lanjut, dan (9) kepuasan dalam belajar.

Sanjaya (2014) menjelaskan strategi pembelajaran ekspositori adalah strategi pembelajaran yang menekankan kepada proses penyampaian materi secara verbal dari seorang guru kepada sekelompok siswa dengan maksud agar siswa dapat menguasai materi pelajaran secara optimal. Selanjutnya Rusmono (2012) menjelaskan strategi pembelajaran ekspositori merupakan bentuk dari pendekatan pembelajaran yang berorientasi kepada guru, karena dalam strategi ini guru memegang peran yang sangat dominan. Melalui strategi ini guru menyampaikan materi pelajaran secara terstruktur dengan harapan materi pelajaran yang disampaikan dapat dikuasai siswa dengan baik. Selanjutnya Gulo (2008) menjelaskan strategi pembelajaran ekspositori dilakukan guru mengolah secara tuntas pesan/materi sebelum disampaikan di kelas sehingga peserta didik tinggal menerima saja.

Safari (2005) minat belajar adalah pilihan kesenangan dalam melakukan kegiatan dan dapat membangkitkan gairah seseorang untuk memenuhi kesediaannya dalam belajar. Minat belajar akan memudahkan terciptanya konsentrasi dan pikiran peserta didik. Perhatian serta merta 
yang diperoleh secara wajar dan tanpa ada kekerasan dari luar akan memudahkan berkembangnya konsentrasi yaitu memusatkan pikiran terhadap pelajaran. Tanpa minat, konsentrasi terhadap pelajaran akan sulit dikembangkan dan dipertahankan. Sementara itu, apabila tidak berminat maka akan menimbulkan kebosanan, kekosongan perhatian, atau bahkan keterlibatan diri terhadap suatu objek.

Menurut Gie (1998) pentingnya minat dalam belajar didasarkan atas: (1) melahirkan sikap serta merta, (2) memudahkan tercapainya konsentrasi, (3) memperkuat melekatnya bahan pelajaran dalam ingatan, dan (4) memperkecil kebosanan studi dalam diri individu. Djamarah dan Zain (2002) menjelaskan minat besar pengaruhnya terhadap aktivitas belajar. Siswa yang berminat terhadap suatu pelajaran akan mempelajarinya dengan sungguh-sungguh, karena adanya daya tarik baginya. Siswa mudah menghafal pelajaran yang menarik minatnya. Proses belajar akan berjalan lancar bila disertai dengan minat.

\section{METODOLOGI PENELITIAN}

Penelitian dilaksanakan di Sekolah Dasar Negeri (SDN) 104192 Tandem Hilir II Deli Serdang. Metode penelitian yang digunakan adalah quasi eksperiment dengan menggunakan desain faktorial $2 \times 2$. Populasi dalam penelitian adalah seluruh siswa kelas V (lima) SDN 104192 Tandem Hilir II Deli Serdang tahun pelajaran 2018/2019 yang terdiri dari 3 (tiga) kelas yang berjumlah 103 siswa. Teknik penentuan sampel digunakan cluster random sampling (pengambilan sampel secara acak berdasarkan kelas/kelompok). Teknik analisis data digunakaan analisis varians dua jalur.

\section{HASIL PENELITIAN DAN PEMBAHASAN}

Rerata hasil belajar Pendidikan Agama Islam siswa SDN 104192 Tandem Hilir II Deli Serdang yang diajar dengan strategi pembelajaran think pair share $(\bar{X}=29,32)$ lebih tinggi daripada rerata hasil belajar Pendidikan Agama Islam siswa yang diajar dengan strategi pembelajaran ekspositori $(\bar{X}=27)$. Selanjutnya berdasarkan pengujian hipotesis menunjukkan hasil yang signifikan yaitu harga $F_{\text {hitung }}(13,32)$ lebih besar dari harga $F_{\text {tabel }}(4,00)$.

Hal ini menunjukkan bahwa strategi pembelajaran think pair share terbukti efektif dapat meningkatkan hasil belajar Pendidikan Agama Islam siswa SDN 104192 Tandem Hilir II Deli Serdang secara keseluruhan baik untuk kelompok siswa dengan minat belajar tinggi maupun kelompok 
siswa dengan minat belajar rendah. Dengan demikian dapatlah dimaknai bahwa strategi pembelajaran think pair share lebih efektif untuk meningkatkan hasil belajar Pendidikan Agama Islam tanpa memperhatikan minat belajar siswa.

Penerapan strategi pembelajaran think pair share dapat mendorong siswa SDN 104192 Tandem Hilir II Deli Serdang untuk aktif belajar karena siswa dapat menghubungkan yang mereka pelajari dengan materi sebelumnya dan struktur kognitif yang sudah dimiliki siswa. Di samping itu strategi pembelajaran think pair share bertujuan menumbuhkan partisipasi siswa dalam memecahkan masalah atau menyelesaikan soal yang diajukan oleh guru dalam pembelajaran, menumbuhkan diskusi di antara siswa dalam mencari penyelesaian atas masalah atau soal tersebut. Oleh karena itu peran guru dalam strategi pembelajaran think pair share lebih dominan sebagai fasilitator yang mengarahkan siswa untuk menemukan dan mengkonstruk sendiri pengetahuannya.

Hal di atas dapatlah dipahami karena strategi pembelajaran think pair share dijelaskan Lie (2004) menjelaskan bahwa strategi pembelajaran think pair share memberikan kesempatan kepada siswa kesempatan untuk bekerja sendiri serta bekerjasama dengan orang lain. Keunggulan lain dari teknik ini sebagaimana dijelaskan Lie adalah optimalisasi partisipasi peserta didik. Jika dibandingkan dengan metode klasikal yang memungkinkan hanya satu peserta didik maju dan membagikan hasilnya untuk seluruh kelas, maka strategi pembelajaran kooperatif think pair share memberikan kesempatan yang relatif lebih banyak kepada peserta didik untuk dikenali dan menunjukkan partisipasi mereka kepada orang lain.

Hal yang sama dipertegas oleh Rahim (2005) bahwa strategi pembelajaran think pair share bisa meningkatkan hasil belajar siswa. Di samping itu berdasarkan pada beberapa penelitian, siswa juga bisa membuat dan menjelaskan prediksi tentang bagaimana masalah bisa diselesaikan dan meringkaskan unsur-unsur utama suatu cerita kepada unsur cerita lainnya.

Strategi pembelajaran think pair share yang dimulai dengan memberikan waktu untuk menganalisis materi atau soal menyebabkan pembelajaran lebih menyenangkan dan membangkitkan ketertarikan dan rasa ingin tahu siswa terhadap materi yang disajikan. Hal ini membuat siswa lebih mudah berkonsentrasi pada materi pembelajaran, dan tentu hal ini menjadikan kegiatan pembelajaran yang dilaksanakan menjadi 
lebih mudah dilaksanakan karena siswa telah tertarik dan berkonsentrasi dalam pembelajaran.

Rasa ingin tahu siswa yang telah terkonsentrasinya siswa akan mempermudah siswa memperoleh pengetahuan baru, sehingga pengetahuan tersebut semakin melekat dan tetap dalam ingatan jangka panjang siswa, dan sewaktu-waktu dapat dibangkitkan kembali untuk kebutuhan belajar siswa, terutama saat guru memberikan latihan pada tahap akhir pelaksanaan pembelajaran dan saat pelaksanaan tes hasil belajar di akhir pertemuan pembelajaran.

Hasil penelitian ini dan temuan penelitian lain menunjukkan bahwa strategi pembelajaran think pair share yang dimulai dengan memberikan waktu membaca teks menyebabkan pembelajaran berlangsung lebih menyenangkan dan membangkitkan ketertarikan dan rasa ingin tahu siswa terhadap materi yang disajikan. Hal ini membuat siswa lebih mudah berkonsentrasi pada materi pembelajaran, dan tentu hal ini menjadikan kegiatan membaca yang dilaksanakan menjadi lebih mudah dilaksanakan karena siswa telah tertarik dan berkonsentrasi dalam pembelajaran. Ketertarikan dan rasa ingin tahu siswa serta telah terkonsentrasinya siswa akan mempermudah siswa memperoleh pengetahuan baru, sehingga pengetahuan tersebut semakin melekat dan tetap dalam ingatan jangka panjang siswa, dan sewaktu-waktu dapat dibangkitkan kembali untuk kebutuhan belajar siswa, terutama saat guru memberikan latihan pada tahap akhir pelaksanaan pembelajaran dan saat pelaksanaan tes hasil belajar di akhir pertemuan pembelajaran

Rerata hasil belajar Pendidikan Agama Islam siswa SDN 104192 Tandem Hilir II Deli Serdang dengan minat belajar tinggi $(\bar{X}=29,90)$ secara keseluruhan baik yang diajar dengan strategi pembelajaran think pair share dan strategi pembelajaran ekspositori lebih tinggi baik daripada rata-rata hasil belajar Pendidikan Agama Islam siswa SDN 104192 Tandem Hilir II Deli Serdang dengan minat belajar rendah $(\bar{X}=26,20)$. Selanjutnya berdasarkan pengujian hipotesis kedua menunjukkan bahwa hasil belajar Pendidikan Agama Islam siswa SDN 104192 Tandem Hilir II Deli Serdang dengan minat belajar tinggi lebih tinggi dari pada siswa dengan minat belajar rendah. Hasil analisis statistik membuktikan di mana harga $F_{\text {hitung }}(10,41)$ lebih besar dari harga $F_{\text {tabel }}(4,00)$.

Hasil ini membuktikan bahwa minat belajar signifikan untuk membedakan hasil belajar Pendidikan Agama Islam siswa. Hal ini dapat dimaklumi karena siswa dengan minat belajar tinggi lebih dapat memahami dan menguasai materi pelajaran Pendidikan Agama Islam 
dibandingkan siswa dengan minat belajar rendah. Minat belajar pada dasarnya merujuk pada perilaku individu. Akan tetapi, karena perilaku merupakan manifestasi dari kondisi psikologi individu, maka untuk mengetahui tingkat minat belajar siswa perlu memperhatikan aspek-aspek psikologi.

Seorang siswa yang memiliki tingkat minat belajar yang tinggi yang mampu meningkatkan hasil belajarnya, karena siswa tersebut terbiasa untuk bertindak kreatif dan inovatif. Minat belajar tinggi mempunyai makna bagi upaya peningkatan kemampuan dalam belajar sekaligus dalam mencapai hasil belajar yang diperolehnya ketika mengikuti satu pelajaran. Selain itu siswa dengan minat belajar tinggi akan bertindak menurut buah pikirannya sendiri sesuai dengan kemampuannya pada akhirnya akan bermuara kepada kematangan pola pikir dan pola belajar serja kemauan belajar yang kuat untuk memperoleh hasil belajar yang lebih baik

Penjelasan di atas sejalan dengan pemaparan Djamarah dan Zain (2002:133) menjelaskan minat besar pengaruhnya terhadap aktivitas belajar. Siswa yang berminat terhadap suatu pelajaran akan mempelajarinya dengan sungguh-sungguh, karena adanya daya tarik baginya. Siswa mudah menghafal pelajaran yang menarik minatnya. Proses belajar akan berjalan lancar bila disertai dengan minat.

Temuan penelitian ini juga mendukung penelitian dilakukan sebelumnya oleh: (1) penelitian Simamora (2014) menunjukkan minat belajar siswa kelas eksperimen meningkat yaitu pertemuan I 63,22\% dan pada pertemuan II 71,42\%. (2) penelitian Rusmiati (2017) menunjukkan berdasarkan analisis korelasi antara hasil angket dan hasil dokumentasi nilai raport siswa diketahui bahwa minat belajar pelajaran ekonomi mempunyai pengaruh yang sedang atau cukup terhadap prestasi belajar bidang studi ekonomi siswa Madrasah Aliyah Al Fattah Sumbermulyo. Angka indeks korelasi minat belajar dengan prestasi belajar bidang studi ekonomi adalah 0,681. (3) penelitian Maulia, Indriayu Alfarisy (2016) menunjukkan terdapat pengaruh yang signifikan antara variabel minat belajar secara parsial terhadap variabel prestasi belajar siswa. Hal ini terlihat dari nilai thitung variabel minat belajar sebesar 4,902 dan nilai $t_{\text {tabel }}$ sebesar 2,000, sehingga $t_{\text {hitung }}>t_{\text {tabel }}(4,902>2,000)$. Nilai $t$ menunjukkan bahwa Ho ditolak dan Ha diterima.

Hasil penelitian ini dan temuan penelitian lainnya menunjukkan bahwa tingkat minat belajar yang terinternalisasi dalam diri diri seorang siswa akan memberikan dukungan terhadap kegiatan belajar yang 
dilakukannya. Minat belajar sebagai satu kekuatan pada diri individu dalam melakukan sesuatu tanpa tergantung orang lain tentunya mempunyai makna yang berarti bagi seorang siswa dalam merencanakan, mengelola dan menyelesaikan kegiatan belajarnya. Dapat diprediksikan bahwa apabila tingkat minat belajar seorang siswa tinggi, maka dapar diharapkan siswa tersebut akan dapat mencapai hasil yang lebih baik dari rekannya. Jadi minat belajar seorang siswa mempunyai makna bagi upaya peningkatan kemampuan dalam belajar sekaligus dalam kerangka mencapai hasil belajar yang diperolehnya.

Rerata hasil belajar Pendidikan Agama Islam siswa SDN 104192 Tandem Hilir II Deli Serdang yang diajar dengan strategi pembelajaran think pair share dan minat belajar tinggi $\quad(\bar{X}=31,38)$ lebih tinggi daripada hasil belajar Pendidikan Agama Islam siswa dengan minat belajar rendah $(\bar{X}=25,38)$. Sedangkan pada strategi pembelajaran ekspositori, rata-rata hasil belajar Pendidikan Agama Islam siswa dengan minat belajar tinggi $(\bar{X}=28,43)$ lebih tinggi daripada hasil belajar Pendidikan Agama Islam siswa dengan minat belajar rendah $(\bar{X}=26,37)$.

Selanjutnya berdasarkan pengujian hipotesis ketiga menunjukkan terdapat interaksi antara strategi pembelajaran dan minat belajar dalam mempengaruhi hasil belajar Pendidikan Agama Islam siswa SDN 104192 Tandem Hilir II Deli Serdang, di mana hasil analisis statistik membuktikan di mana harga $F_{\text {hitung }}(12,51)$ lebih besar dari harga $F_{\text {tabel }}$ $(4,00)$.

Memperhatikan keterangan di atas maka dapat dilihat bahwa: (1) rerata hasil belajar Pendidikan Agama Islam pada kelompok siswa dengan minat belajar tinggi dan diajar dengan strategi pembelajaran think pair share lebih tinggi dibandingkan dengan rata-rata hasil belajar Pendidikan Agama Islam kelompok siswa dengan minat belajar rendah dan diajar dengan strategi pembelajaran ekspositori, dan (2) rerata hasil belajar Pendidikan Agama Islam pada kelompok siswa dengan minat belajar rendah dan diajar dengan strategi pembelajaran think pair share lebih rendah dibandingkan dengan rata-rata hasil belajar Pendidikan Agama Islam kelompok siswa dengan minat belajar rendah dan diajar dengan strategi pembelajaran ekspositori.

Kelompok siswa dengan minat belajar rendah lebih baik diajar dengan menggunakan strategi pembelajaran ekspositori dibandingkan dengan menggunakan strategi pembelajaran think pair share. Dengan demikian dapatlah ditarik kesimpulan bahwa strategi pembelajaran dan 
minat belajar signifikan mempengaruhi hasil belajar Pendidikan Agama Islam siswa.

Minat belajar merupakan salah faktor yang signifikan untuk membedakan hasil belajar Pendidikan Agama Islam siswa, di mana hasil belajar Pendidikan Agama Islam siswa dengan minat belajar tinggi, baik yang diajar dengan strategi pembelajaran think pair share maupun strategi pembelajaran ekspositori lebih tinggi daripada hasil belajar Pendidikan Agama Islam siswa dengan minat belajar rendah. Secara khusus bagi siswa dengan minat belajar rendah dalam kegiatan pembelajaran Pendidikan Agama Islam diberikan tugas-tugas yang lebih banyak sehingga dapat menutupi kelemahan terhadap penguasaan materi Pendidikan Agama Islam.

\section{SIMPULAN}

Simpulan-simpulan yang dapat ditarik dari hasil penelitian adalah sebagai berikut: (1) rata-rata hasil belajar Pendidikan Agama Islam siswa yang diajar dengan strategi pembelajaran think pair share lebih tinggi dibandingkan dengan rata-rata hasil belajar Pendidikan Agama Islam siswa yang diajar dengan strategi pembelajaran ekspositori. Dengan demikian strategi pembelajaran think pair share lebih efektif diterapkan dalam pembelajaran Pendidikan Agama Islam guna meningkatkan hasil belajar Pendidikan Agama Islam siswa tanpa memperhatikan adanya perbedaan minat belajar, (2) rata-rata hasil belajar Pendidikan Agama Islam siswa dengan minat belajar tinggi yang diajar dengan strategi pembelajaran think pair share maupun strategi pembelajaran ekspositori lebih tinggi dibandingkan dengan rata-rata hasil belajar Pendidikan Agama Islam siswa dengan minat belajar rendah, dan (3) terdapat interaksi antara strategi pembelajaran dan minat belajar siswa yang memberikan perbedaan pengaruh terhadap hasil belajar Pendidikan Agama Islam.

\section{SARAN}

Berdasarkan hasil temuan-temuan penelitian sebelumnya maka dapatlah disampaikan beberapa saran sebagai berikut: (1) strategi pembelajaran dan karakteristik siswa merupakan suatu komponen yang dapat menentukan dan mempengaruhi hasil belajar. Oleh karena itu guru sebagai perancang pembelajaran memperhatikan strategi pembelajaran dan karakteristik siswa dalam merancang pembelajaran sehingga dengan demikian guru dapat menetapkan pilihan strategi pembelajaran yang 
lebih sesuai dengan karakteristik siswa untuk dilaksanakan, (2) karakteristik siswa yang diteliti dari penelitian ini hanya terbatas kepada minat belajar. Untuk itu kepada peneliti lain disarankan untuk meneliti karakteristik siswa yang lain misalnya kemampuan awal, retensi, motivasi belajar, gaya belajar, dan (3) Strategi pembelajaran think pair share diterapkan pada mata pelajaran Pendidikan Agama Islam dan pada ranah kognitif, disarankan untuk peneliti lain dapat meneliti dalam bidang studi lainnya.

\section{DAFTAR PUSTAKA}

Arend, I. Richard. (2008) Learning To Teaching. Buku Dua. Penerjemah Helly Prajitno Soetjipto dan Sri Mulyantini Soetjipto, Yogyakarta: Pustaka Pelajar.

Budiwibowo,Satrijo. (2016) Hubungan Minat Belajar Siswa Dengan Hasil Belajar IPS Di SMP Negeri 14 Kota Madiun. Jurnal: Gulawentah, Jurnal Studi Sosial Volume 1 Nomor 1 Juli 2016.

Djamarah, Syaiful Bahri. Dkk, (2002). Strategi Belajar Mengajar. Jakarta: Rineka Cipta.

Gie, T. Liang. (1998) Cara Belajar Yang Efisien. Yogyakarta: PUBIB.

Gulo, W. (2008) Strategi Belajar Mengajar. Jakarta: Grasindo.

Lie, Anita. (2004) Cooperative Learning. Mempraktekkan Cooperative Learning di Ruang-ruang kelas. Jakarta: Grasindo.

Mudhoffir, (2003) Teknologi Instruksional. Bandung: Rosdakarya.

Nisa, Rahmatun., Musdi, Edwin. Dan Jazwinarti. Penerapan Pembelajaran Kooperatif Tipe Think Pair Share Pada Pembelajaran Matematika Di Kelas XI IPS SMA Negeri 2 Padang Panjang. Jurnal Pendidikan Matematika Vol. 3 No. 12014.

Nitalia, Siti Ropika. (2015) Pengaruh Gaya Belajar Dan Minat Belajar Siswa Terhadap Prestasi Belajar Matematika. Jurnal: Akademis dan Gagasan matematika Edisi Ke Dua Tahun 2015.

Nurdin, Elan Artono. dkk. Pengaruh Model Pembelajaran Think Pair And Share Ditinjau Dari Kemandirian Belajar Terhadap Hasil Belajar IPS Siswa. Jurnal: Jurnal Ilmiah Ilmu Pendidikan, Ilmu Ekonomi, dan Ilmu Sosial Volume 11 Nomor 2, 2017. 
Rusmiati. Pengaruh Minat Belajar Terhadap Prestasi Belajar Bidang Studi Ekonomi Siswa MA Al Fattah Sumbermulyo. Jurnal: Utility Jurnal Ilmiah Pendidikan dan Ekonomi Volume 1, No. 1, Februari 2017.

Rusmono, (2012) Strategi Pembelajaran Dengan Problem Based Learning Itu Perlu Untuk Meningkatkan Porfesionalitas Guru. Bogor: Ghalia Indonesia

Safari. (2005) Evaluasi Hasil Belajar. Yogyakarta: Pustaka Belajar.

Sanjaya, Wina. (2014) Strategi Pembelajaran, Berorientasi Standar Proses Pendidikan. Jakarta: Prenada Media Group.

Simamora, Pintor dan Dalimunthe, Asmidar. Pengaruh Model Pembelajaran Kooperatif Tipe Think Pair Share (TPS) Berbantuan Peta Konsep Terhadap Hasil Belajar Fisika Siswa. Jurnal: Inpafi Vol. 2, No. 2, Mei 2014

Siregar, Eveline dan Nara, Hartini. (2011) Teori Belajar Dan Pembelajaran. Bogor: Ghalia Indonesia.

Solihatin, E. dan Raharjo. (2008) Cooperative Learning Analisis Model Pembelajaran IPS. Jakarta: Bumi Aksara.

Suparman, M. Atwi. (2012) Desain Instruksional Modern Panduang Para Pengajar Dan Inovator Pendidikan. Jakarta: Erlangga. 